\title{
Spontaneous Remission in Paroxysmal Nocturnal Hemoglobinuria: An Extremely Rare Case
}

\author{
Paroksismal Noktürnal Hemoglobinüride Spontan Remisyon: Çok Nadir Bir Olgu
}

(1) Özgür Mehtap, (1) Ayfer Gedük

Kocaeli University Faculty of Medicine, Department of Hematology, Kocaeli, Turkey

\section{To the Editor,}

Paroxysmal nocturnal hemoglobinuria (PNH) is an acquired clonal disease with the main clinical manifestations of hemolytic anemia, bone marrow failure, and thrombophilia [1]. While it was previously reported that spontaneous remission develops in 15\%-30\% of patients with $\mathrm{PNH}$, this rate is as low as $3 \%$ in recent studies $[2,3,4,5]$. This inconsistency between results is probably due to the differences in the definitions of "spontaneous remission" used in these studies and the analysis methods applied. Herein, we present a rare case of aplastic anemia/PNH overlap syndrome where the patient achieved remission under immunosuppressive and anticomplement therapy.
In 2012, a 24-year-old female patient was admitted to our hospital due to severe fatigue. Pancytopenia was detected in the complete blood count. Biochemical analysis was normal, except for a slight increase in lactate dehydrogenase and a low haptoglobin level. Bone marrow biopsy revealed decreased bone marrow cellularity (40\%) and relative erythroid hyperplasia. A flow cytometric evaluation revealed a PNH granulocyte clone size of 56.3\%. The patient was started on eculizumab treatment, which continued for 6 years. PNH clone percentages and clinical parameters over the years are shown in Table 1. The PNH clone size gradually decreased from $56.3 \%$ to $12.96 \%$ under eculizumab treatment. Repeated bone marrow biopsy revealed

\begin{tabular}{|c|c|c|c|c|c|}
\hline & Type II erythrocytes, \% & Type III erythrocytes, \% & Total erythrocytes, \% & Monocytes, \% & Granulocytes, \% \\
\hline 2012 & 2.75 & 11.63 & 14.38 & 48 & 56.3 \\
\hline 2013 & 1.18 & 19.5 & 21.3 & 51.6 & 55 \\
\hline 2014 & 1 & 13.9 & 14.9 & 40.3 & 46.5 \\
\hline 2015 & 0.75 & 13 & 13.75 & 42.4 & 45 \\
\hline 2016 & 0.28 & 12.56 & 12.84 & 48.5 & 42.6 \\
\hline 2017 & 0.10 & 8.9 & 9 & 24.5 & 31.76 \\
\hline 2018 & 10.95 & 10.53 & 21.48 & 11.05 & 12.96 \\
\hline 2019 & 1.81 & 0.11 & 1.92 & 4.52 & 4.86 \\
\hline 2020 & 1.68 & 0.04 & 1.72 & 4.26 & 3.58 \\
\hline \multirow[t]{2}{*}{2021} & 0.1 & 1.1 & 1.2 & 1.39 & 0.72 \\
\hline & Neutrophils, $/ \mathrm{mm}^{3}$ & Hemoglobin, g/dL & Platelets, $/ \mathrm{mm}^{3}$ & LDH, NR: 135-225 IU/L & $\begin{array}{l}\text { Haptoglobin, } \\
\text { NR: } 30-200 \mathrm{mg} / \mathrm{dL}\end{array}$ \\
\hline 2012 & 950 & 8.9 & 44,000 & 297 & 8 \\
\hline 2013 & 1380 & 9.26 & 90,300 & 123 & 77 \\
\hline 2014 & 1340 & 9.6 & 107,000 & 144 & 63 \\
\hline 2015 & 4750 & 11.2 & 90,300 & 129 & 97 \\
\hline 2016 & 1730 & 13.3 & 89,800 & 152 & 93 \\
\hline 2017 & 1513 & 10.8 & 82,900 & 146 & 81 \\
\hline 2018 & 695 & 10.67 & 48,700 & 180 & 138 \\
\hline 2019 & 1634 & 11.13 & 95,000 & 150 & 99 \\
\hline 2020 & 1896 & 11.89 & 102,000 & 187 & 118 \\
\hline 2021 & 2119 & 13.69 & 123,700 & 171 & 106 \\
\hline \multicolumn{6}{|c|}{ LDH: Lactate dehydrogenase; NR: normal range. } \\
\hline
\end{tabular}


a decrease in cellularity to $35 \%$ and, due to the tendency of a decreasing platelet count, cyclosporine was added to the treatment at $200 \mathrm{mg} /$ day. After 1 year of combined treatment, the pancytopenia was resolved, PNH clone size had decreased to $4.86 \%$, and follow-up bone marrow biopsy showed an increase in cellularity (65\%). With these results, eculizumab and cyclosporine treatment was discontinued in 2019. The PNH clone size of the patient, who is still asymptomatic 27 months after the cessation of treatment, continues to shrink. During the entire clinical course, the patient did not need transfusions and no complications related to PNH developed.

The disappearance of the PNH clone may be due to various causes, such as complete recovery, deepening of bone marrow aplasia, or transformation to leukemia. However, the underlying mechanisms and the reasons for complete recovery are unknown. One of the hypotheses put forward is that clones of cells affected by PNH have a limited lifespan like normal somatic cells [3]. There are also cases in the literature that draw attention to the relationship between pathological PNH clones and bone marrow environmental conditions $[6,7]$. Recent studies have shown that PNH is a multiclonal disease and hosts additional somatic mutations that result in a complex hierarchical clonal architecture similar to that observed in myeloid neoplasms. Thus, it has been suggested that remission of PNH may occur through the emergence of a new dominant clone carrying multiple somatic mutations rather than restoration of normal hematopoiesis $[5,8,9]$. As a result, the highly variable clinical spectrum of PNH is also reflected in cases of remission. Understanding the underlying pathophysiology of this extremely rare condition will form the basis for the development of curative treatments for the disease.

Keywords: Aplastic anemia, Paroxysmal nocturnal hemoglobinuria, Eculizumab, Cyclosporine

Anahtar kelimeler: Aplastik anemi, Paroksismal noktürnal hemoglobinüri, Ekulizumab, Siklosporin

\section{Authorship Contributions}

Surgical and Medical Practices: Ö.M, A.G.; Concept: Ö.M, A.G.; Design: Ö.M, A.G.; Data Collection or Processing: Ö.M, A.G.;
Analysis or Interpretation: Ö.M, A.G.; Literature Search: Ö.M, A.G.; Writing: Ö.M, A.G.

Conflict of Interest: No conflict of interest was declared by the authors.

Financial Disclosure: The authors declared that this study received no financial support.

\section{References}

1. Parker $C$, Omine $M$, Richards $S$, Nishimura J, Bessler $M$, Ware $R$, Hillmen P, Luzzatto L, Young N, Kinoshita T, Rosse W, Socié G; International PNH Interest Group. Diagnosis and management of paroxysmal nocturnal hemoglobinuria. Blood 2005;106:3699-3709.

2. Muñoz-Linares $C$, Ojeda $E$, Forés $R$, Pastrana $M$, Cabero $M$, Morillo $D$, Bautista $G$, Baños I, Monteserin C, Bravo P, Jaro E, Cedena T, Steegmann JL, Villegas A, Cabrera JR. Paroxysmal nocturnal hemoglobinuria: a single Spanish center's experience over the last 40 yr. Eur J Haematol 2014;93:309-319.

3. Hillmen P, Lewis SM, Bessler M, Luzzatto L, Dacie JV. Natural history of paroxysmal nocturnal hemoglobinuria. N Engl J Med 1995;333:1253-1258.

4. Korkama ES, Armstrong $A E$, Jarva $H$, Meri S. Spontaneous remission in paroxysmal nocturnal hemoglobinuria-return to health or transition into malignancy? Front Immunol 2018;9:1749.

5. Gurnari C, Pagliuca S, Kewan T, Bahaj W, Mori M, Patel BJ, Visconte V, Maciejewski JP. Is nature truly healing itself? Spontaneous remissions in paroxysmal nocturnal hemoglobinuria. Blood Cancer J 2021;11:187.

6. Pulini $S$, Marando L, Natale A, Pascariello C, Catinella V, Del Vecchio L, Risitano AM, Fioritoni G. Paroxysmal nocturnal hemoglobinuria after autologous stem cell transplantation: extinction of the clone during treatment with eculizumab - pathophysiological implications of a unique clinical case. Acta Haematol 2011;126:103-109.

7. Hakim F, Childs R, Balow J, Cowan K, Zujewski J, Gress R. Development of paroxysmal nocturnal hemoglobinuria after chemotherapy. Blood 1996;88:4725-4726.

8. Shen W, Clemente MJ, Hosono N, Yoshida K, Przychodzen B, Yoshizato T, Shiraishi Y, Miyano S, Ogawa S, Maciejewski JP, Makishima H. Deep sequencing reveals stepwise mutation acquisition in paroxysmal nocturnal hemoglobinuria. J Clin Invest 2014;124:4529-4538.

9. Babushok DV, Stanley N, Xie HM, Huang H, Bagg A, Olson TS, Bessler $M$. Clonal replacement underlies spontaneous remission in paroxysmal nocturnal haemoglobinuria. Br J Haematol 2017;176:487-490.
Received/Geliş tarihi: December 7, 2021 Accepted/Kabul tarihi: January 27, 2022

DOI: 10.4274/tjh.galenos.2022.2021.0672 